\title{
Genetic evidence for mixed origin of recolonized sea trout populations
}

\author{
HALVOR KNUTSEN*†, JAN ATLE KNUTSEN $\$$ \& PER ERIK JORDE $\dagger$ \\ $\dagger$ Division of Zoology, Department of Biology, University of Oslo, PO Box 1050 Blindern, N-0316 Oslo, Norway \\ and $\ddagger$ Institute of Marine Research, Flødevigen Marine Research Station, N-4817 His, Norway
}

\begin{abstract}
Anadromous brown trout along the Norwegian Skagerrak coast are genetically differentiated among streams, and there are indications of further substructuring within some streams. Among presumably long-standing populations there is a pattern of increased genetic differentiation with distance, indicating an isolation-by-distance effect. For trout that inhabit streams that have recently been recolonized after the extinction of trout because of acidification, we find evidence for a mixed origin of the recolonizing trout. Both the high levels of gametic phase disequilibrium and the clear deviation from the general pattern of increased genetic differentiation with distance that are seen in recolonized streams, are consistent with recent population admixture, and confirm the loss of the original populations of these acid streams.
\end{abstract}

Keywords: dispersal, genetic differentiation, isozymes, recolonization, Salmo trutta.

\section{Introduction}

The southern part of Norway has experienced massive extinction of freshwater and anadromous fish populations, in particular of the brown trout (Salmo trutta) and salmon (S. salar), following acidification in the 1960s to the early 1980s (Jensen \& Snekvik, 1972; Henriksen et al., 1989). This acidification was mainly due to airborne pollutants of anthropogenic origin, and its effect in southern Norway was severe, because most areas have a granite bedrock with poor buffering capacity (Henriksen et al., 1989). As a means to counteract acidification and fish extinction, large-scale programmes were initiated by the government in 1983 to restore $\mathrm{pH}$ values to acceptable levels through the release of lime and marl directly into the watercourses. This liming has proven successful in many localities (Kaste \& Håvardstun, 1998) and several previously empty lakes and streams have regained apparently healthy stocks of brown trout during the last few years (Simonsen, 1999). This restoration of brown trout populations has occurred naturally and without manassisted introductions. At present, we do not know the details of the recolonization events or from where the colonizing trout originated.

Earlier genetic studies of freshwater resident and anadromous brown trout ('sea trout') have found that this species is characterized by moderately large genetic

\footnotetext{
*Correspondence. E-mail: halvor.knutsen@bio.uio.no
}

differences among local populations (e.g. Ryman, 1983; Ferguson, 1989). Typically, nearby localities harbour distinct local populations and genetically distinct populations may even occur in sympatry within the same lake or stream (Allendorf et al., 1976; Ryman et al., 1979; Ferguson \& Mason, 1981; Jorde \& Ryman, 1996; Carlsson et al., 1999). The explanation for this strong tendency to group into partially isolated populations is most likely found in a well-developed homing behaviour, as verified by olfactory, mark-release-recapture, and telemetry studies (e.g. Stuart, 1957; Svärdson \& Fagerström, 1982; Lund \& Hansen, 1992; Stabel, 1992; Ovidio, 1999). However, physical conditions are also likely to play an important rôle, as genetic differentiation is most pronounced among freshwater resident populations with limited possibilities for dispersal and gene-flow (e.g. Ferguson, 1989), whereas anadromous populations, with ample possibilities for gene-flow, are usually less differentiated genetically (e.g. Paaver, 1989; Morán et al., 1995; Hansen \& Mensberg, 1998).

Although homing is well documented in brown trout, little is known about patterns of extinction and recolonization in this species. For freshwater resident brown trout, it has been observed that previously extinct streams have been recolonized by trout originating nearby (Beaudou et al., 1995; Hansen \& Mensberg, 1996). Hansen \& Mensberg (1996) also found genetic evidence of substantial contributions from a single, closely situated, source population. Little is currently known about the recolonization process in anadromous 
brown trout, however. With a much larger potential for dispersal in anadromous trout, potential colonizers could conceivably originate from a much wider geographical region than is the case with freshwater forms, possibly including several donor populations. The pattern of extinction and recolonization, and the question of the origin of recolonizing fish, is important because effective management of this and other species requires knowledge about the population system (in which the local populations exist). Such systems existing in a balance between extinction and recolonization are called metapopulations (e.g. Levins, 1970).

Metapopulation systems represent challenges to management because they are dynamic entities where extinction and recolonization are the norms rather than the exceptions. Such dynamics of change may drastically affect both levels of genetic variation within populations and genetic differentiation among populations (Gilpin, 1991). For this reason it is important to establish whether the species consists of such dynamic population systems or if it consists of local populations that are safely managed in isolation. Wade \& McCauley (1988) distinguished between two models of recolonization for population systems, the propagule model and the migrant model. The first of these models assumes that recolonization occurs from one single source population, whereas in the other model, migrants may be derived from several source populations.
The objective of the present study is to find out if the extinctions caused by acid precipitation in southern Norway, and the subsequent recovery following de-acidification, have had an impact on the genetic constitution of anadromous brown trout. Because we do not have access to samples prior to the acidification, we elucidate recolonization processes by comparing genetic differentiation patterns among long-standing and recently recolonized sea trout streams.

\section{Materials and methods}

Juvenile brown trout (Salmo trutta) were collected by electrofishing in eight streams along the south-east coast of Norway (Fig. 1; Table 1). No farming or stocking of hatchery-reared brown trout occurs in the area. Sampling of juveniles (the so-called 0-group) was performed in mid June, when they were about $4-6 \mathrm{~cm}$ long. About 80 individuals were sampled from each stream, taking care to ensure representative sampling from the whole stream in order to avoid overrepresentation of family groups (cf. Allendorf \& Phelps, 1981).

The eight streams are comparable in size, about 1-4 km long and 1-3 m wide. They have fairly stable environmental conditions and are permanent, with sufficient discharge also during the dry season (Simonsen, 1999). The breeding grounds extend about 300-1000 m, and juvenile trout were collected evenly along this range.

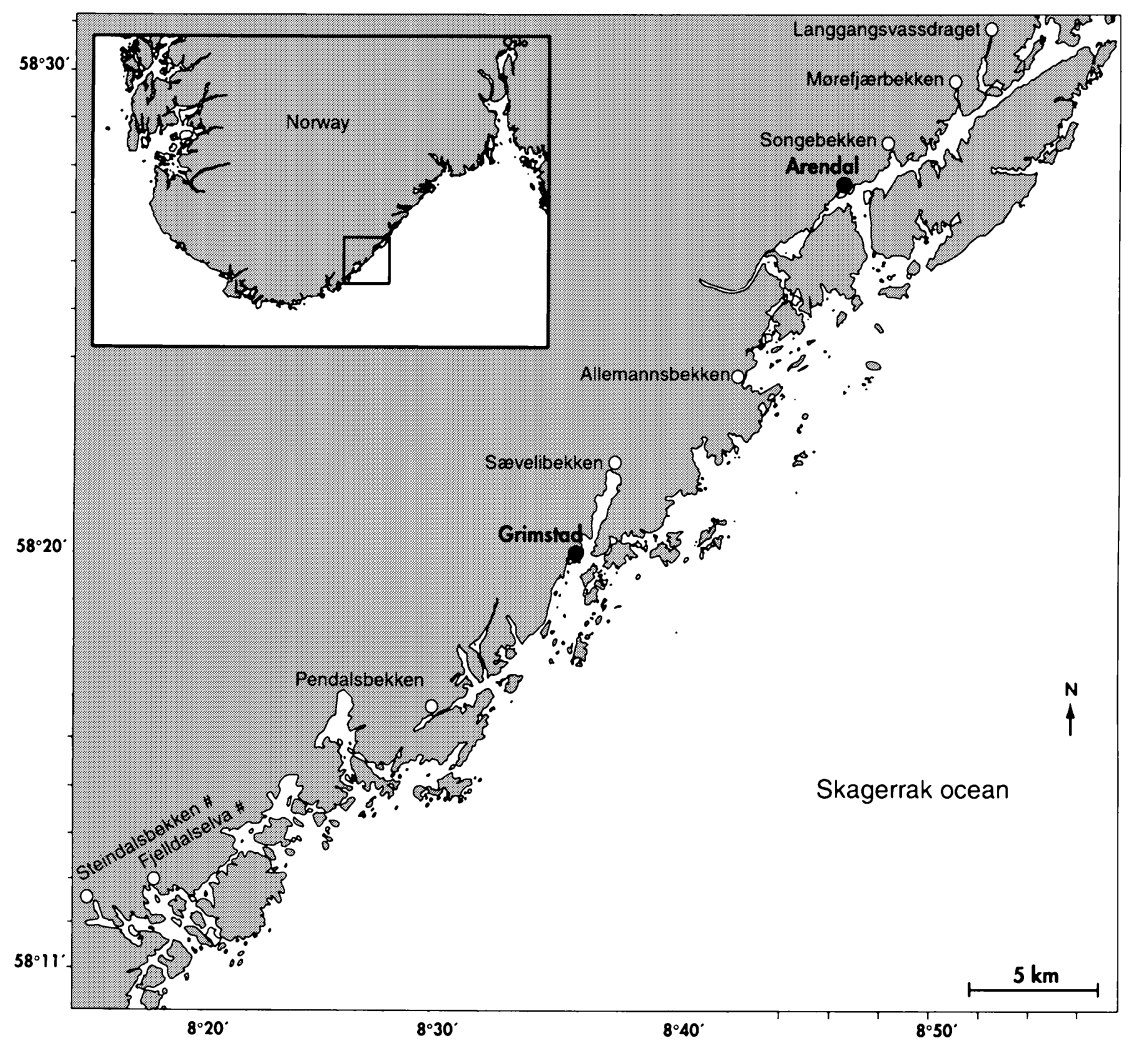

Fig. 1 Map of the south coast of Norway indicating the location of the streams (open circles) where sea trout were sampled. Nearby cities are indicated by solid dots.

(C) The Genetics Society of Great Britain, Heredity, 87, 207-214. 


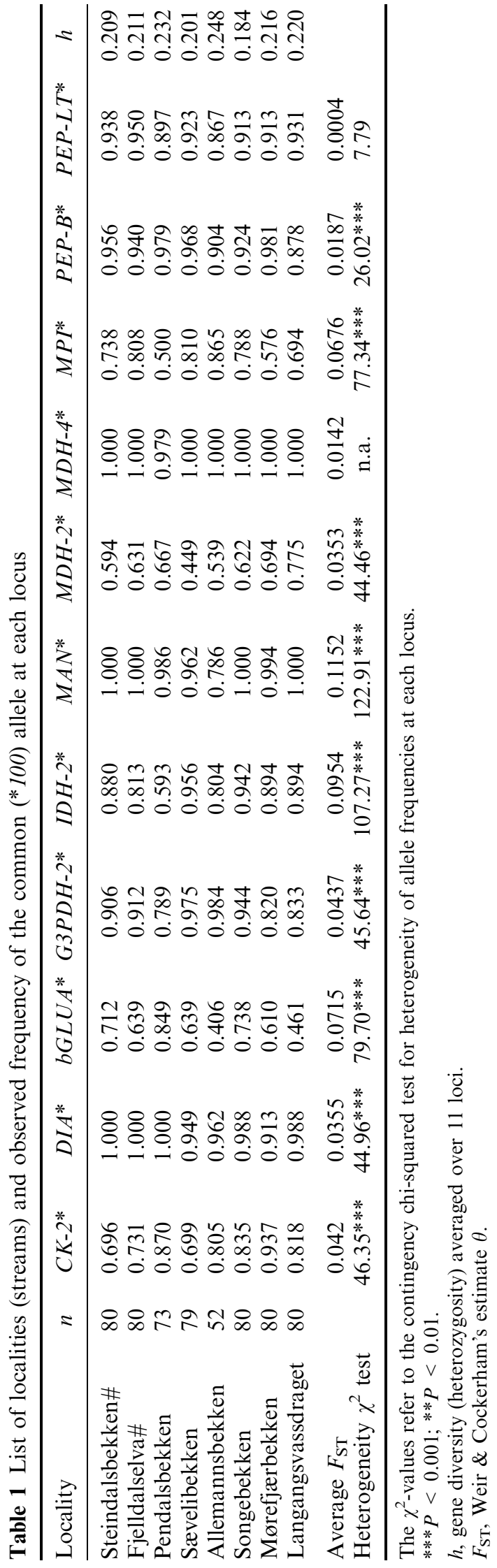

Two of the eight streams, Fjelldalselva and Steindalsbekken, became acidic in the 1970s and 1980s and the trout inhabiting these streams probably went extinct during that time (Simonsen, 1999). The present brown trout populations in these two streams, from which our samples are taken, have most likely been established from fish originating elsewhere and which have recently recolonized the two streams. For clarity, we append the character \# to the name of these streams to distinguish them from the others. The six remaining streams (hereafter 'permanent streams') have probably not experienced any extinction in recent time, and may have persisted for centuries or longer, perhaps since after the last glacial period (personal communication by Fish Management Officer Dag Matzov; Department of Environmental Affairs, County Governor in Aust-Agder).

Tissue samples of white skeletal muscle, liver and eye were stored in an ultrafreezer at $-80^{\circ} \mathrm{C}$ until genetic analyses. Horizontal starch gel electrophoresis was performed as described by Aebersold et al. (1987), screening a selected set of 15 allozyme-coding loci that were previously known to be polymorphic in Scandinavian brown trout (Jorde, 1994): $C K-2^{*}, D I A^{*}, b G L U A^{*}$, G3PDH-2*, GPI-1*, GPI-2*, GPI-3*, IDH-2*, LDH-1*, $M A N^{*}, M D H-2^{*}, M D H-4^{*}, M P I^{*}, P E P-B^{*}$, and $P E P-L T^{*}$. Nomenclature for loci, alleles, and genotypes follows Shaklee et al. (1990).

Allele and genotype frequencies were estimated from samples by gene counting. Average heterozygosity ('gene diversity', $h$ ) within populations was estimated according to Nei \& Chesser (1983). Deviations from Hardy-Weinberg genotype proportions were tested with the chi-squared goodness-of-fit test and quantified by Wright's $F_{\text {IS }}$ averaged over loci (Weir \& Cockerham, 1984). Non-random association of alleles between loci was quantified by the linkage disequilibrium coefficient, $D$, and the standardized measure $D^{\prime}=D / D_{M A X}$, following Lewontin (1964). We included all pairs of loci in which both loci displayed any polymorphism.

Heterogeneity of allele frequencies among streams was tested against the null hypothesis of equal allele frequencies with the contingency chi-squared test. The genetic structure was characterized by Wright's $F_{\mathrm{ST}}$, using Weir \& Cockerham's (1984) estimator $\theta$. $F_{\text {ST }}$ was estimated both as an average over streams and also pair-wise among each pair of streams. We used the bootstrapping procedure, resampling loci, to calculate standard errors for the various $F_{\mathrm{ST}}$ values. Separate average $F_{\mathrm{ST}}$ values were calculated for all streams and for the permanent streams only, excluding the two recolonized Fjelldalselva\# and Steindalsbekken\#. We looked for a geographical pattern in the population genetic structure by regressing pair-wise $F_{\mathrm{ST}} /\left(1-F_{\mathrm{ST}}\right)$ values against the logarithm of geographical distance 
(Rousset, 1997). A positive regression was tested for by a Mantel test (Mantel, 1967), using the permutation procedure in the GENEPOP software (version 3.1d: Raymond \& Rousset, 1995). We calculated likelihood values for each individual belonging to the sampled streams using multilocus genotypes in a Bayesian method with the GENECLASS software (Cornuet et al., 1999). The results are reported as the percentage of individuals correctly assigned to each of the sampled streams. Finally, a mixed fishery analysis was done with the permanent populations as baseline populations and the recolonized ones treated as mixed populations with the WHICHRUN software (version 4.0: Banks \& Eichert, 2000).

\section{Results}

Genetic variation was found in 11 of the 15 loci: $C K-2^{*}$, $D I A^{*}, b G L U A^{*}, G 3 P D H-2^{*}, I D H-2^{*}, M A N^{*}, M D H-2^{*}$, $M D H-4^{*}, M P I^{*}, P E P-B^{*}$, and $P E P-L T^{*}$. At each locus only two alleles were found, of which the frequencies of the common, or $100^{*}$, allele are given in Table 1 . All 11 loci except $D I A^{*}, M A N^{*}$, and $M D H-4^{*}$ were polymorphic in all eight streams. The average heterozygosity was similar, ranging from 0.184 to 0.248 , and not significantly different among streams ( $t$-test among all pairs of streams; $P>0.1$, cf. Table 1).

The samples of trout generally conformed to HardyWeinberg expectations with a few exceptions (Table 2). In three streams there was significant excess of heterozygotes at one locus each $\left(C K-2^{*}\right.$ in Fjelldalselva\#, $P<0.05 ; M P I^{*}$ in Pendalsbekken, $P<0.01$; and $b G L U A^{*}$ in Sævelibekken, $\left.P<0.05\right)$. Significant deficiencies of heterozygotes were detected at five loci in three streams $\left(P E P-L T^{*}\right.$ in Pendalsbekken, $P<0.01$; $D I A^{*}$ and $P E P-L T^{*}$ in Allemannsbekken, $P<0.01$ at both loci and $G 3 P D H-2^{*}$ and $b G L U A^{*}$ in Langangsvassdraget, $P<0.01$ at both loci). Averaged over all polymorphic loci, these results yielded an average excess of heterozygotes (i.e. a negative $F_{\text {Is-value) in four }}$ streams, none of which was significant, and a deficiency of heterozygotes (positive $F_{\text {IS }}$ ) in four streams, significantly so in Allemannsbekken and Langangsvassdraget (Table 2).

Deviations from linkage equilibrium (gametic phase equilibrium) were high in three of the eight streams (Table 2). The two recolonized streams, Fjelldalselva\# and Steindalsbekken\#, both displayed large average $D / D_{\mathrm{MAX}}$ values that were highly significant $(P<0.001$ for each: Table 2). A slightly lower, but still significant $(P<0.01)$ overall linkage disequilibrium value was also observed in the permanent stream Langangsvassdraget, which is one of the two streams where a significant deficiency of heterozygotes was also detected (above; Table 2).

There is considerable genetic differentiation among the sea trout streams. For 9 of the 11 loci (all except $\left.P E P-L T^{*}\right)$ allele frequency heterogeneity is highly significant among streams (Table 1; Table 3), with an average measure of genetic differentiation, $F_{\mathrm{ST}}=0.054$ (ranging from $<0.001$ for $P E P-L T^{*}$ to 0.115 for $M A N^{*}$; Table 1). There is however, a notable difference among pairs of streams in the degree of genetic differentiation between them. The two recolonized streams, Fjelldalselva\# and Steindalsbekken\#, appear very similar genetically, with a pairwise $F_{\mathrm{ST}}$ value of only 0.001 (Table 3 ), whereas, among the permanent streams, the pair-wise $F_{\mathrm{ST}}$ values are generally much

\begin{tabular}{|c|c|c|c|c|}
\hline \multirow[b]{3}{*}{ Locality } & \multicolumn{3}{|c|}{ Within loci } & \multirow{3}{*}{$\begin{array}{l}\text { Between loci } \\
D / D_{\text {MAX }} \text { (SD) }\end{array}$} \\
\hline & \multirow[b]{2}{*}{$F_{\mathrm{IS}}(\mathrm{SD})$} & \multicolumn{2}{|c|}{ Heterozygote } & \\
\hline & & Excess & Deficiency & \\
\hline Steindalsbekken\# & $-0.027(0.097)$ & 6 & 2 & $0.263(0.321)^{* * *}$ \\
\hline Fjelldalselva\# & $-0.037(0.114)$ & $5^{1 * *}$ & 3 & $0.279(0.222)^{* * *}$ \\
\hline Pendalsbekken & $0.022(0.189)$ & $6^{1 * *}$ & $4^{1 * *}$ & $0.048(0.650)$ \\
\hline Sævelibekken & $-0.055(0.081)$ & $8^{1 * *}$ & 2 & $0.146(0.538)$ \\
\hline Allemannsbekken & $0.167(0.186)^{* *}$ & 2 & $7^{2 * *}$ & $0.041(0.596)$ \\
\hline Songebekken & $0.004(0.086)$ & 6 & 3 & $0.021(0.527)$ \\
\hline Mørefjærbekken & $-0.026(0.052)$ & 7 & 2 & $0.100(0.594)$ \\
\hline Langangsvassdraget & $0.096(0.168)^{*}$ & 4 & $5^{2 * *}$ & $0.205(0.459)^{* *}$ \\
\hline Average (SD) & $0.018(0.076)$ & & & $0.138(0.102)$ \\
\hline
\end{tabular}

Table 2 Average measures and tests for genetic disequilibria at 11 loci in eight sea trout populations

'Within loci' refers to deviations from Hardy-Weinberg genotype proportions (excesses and deficiencies of heterozygotes), quantified by the average $F_{\mathrm{IS}}$; 'between loci' refers to tests for gametic phase disequilibria and is reported as the average value of the standardized measure $D / D_{\text {MAX }}$ over all locus pairs.

$* P<0.05 ; * * P<0.01 ; * * P<0.001$. 
Table 3 Genetic differentiation (pair-wise $F_{\mathrm{ST}}$ values) among the eight streams. Significance values were calculated by bootstrapping over loci

\begin{tabular}{|c|c|c|c|c|c|c|c|}
\hline & $1 \#$ & $2 \#$ & 3 & 4 & 5 & 6 & 7 \\
\hline 1 Steindalsbekken\# & - & & & & & & \\
\hline 2 Fjelldalselva\# & 0.001 & - & & & & & \\
\hline 3 Pendalsbekken & $0.074 * *$ & $0.080^{* *}$ & - & & & & \\
\hline 4 Sævelibekken & $0.014 * *$ & $0.022 * *$ & $0.136 * *$ & - & & & \\
\hline 5 Allemannsbekken & $0.065^{* *}$ & $0.043 * *$ & $0.150^{* *}$ & $0.047^{* *}$ & - & & \\
\hline 6 Songebekken & $0.008^{*}$ & $0.012 *$ & $0.093 * *$ & $0.024^{* *}$ & $0.072 * *$ & - & \\
\hline 7 Mørefjærbekken & $0.044 * *$ & $0.046^{* *}$ & $0.058 * *$ & $0.077 * *$ & $0.086^{* *}$ & $0.039^{* *}$ & - \\
\hline 8 Langangsvassdraget & $0.044 * *$ & $0.030^{* *}$ & $0.104 * *$ & $0.075^{* *}$ & $0.055^{* *}$ & $0.048 * *$ & $0.023 * *$ \\
\hline
\end{tabular}

$* P<0.05 ; * * P<0.001$.

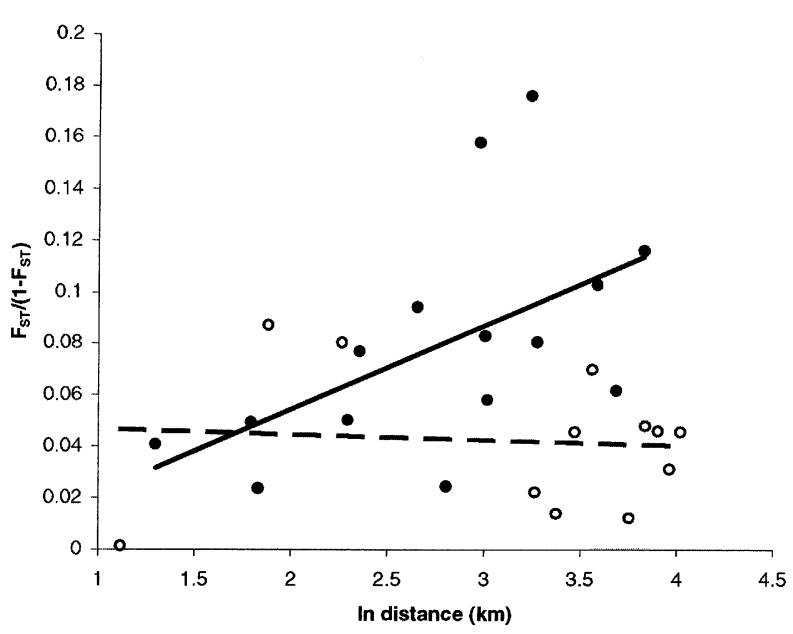

Fig. 2 Scatterplot of pair-wise $F_{\mathrm{ST}} /\left(1-F_{\mathrm{ST}}\right)$-values regressed against logarithmic distance for sea trout streams along the south-east coast of Norway. Filled circles represent pairs of 'permanent' sea trout streams; open circles pairs of streams where at least one was recolonized. The solid line is the regression line for permanent populations and the dotted line for recolonized populations compared to the permanent ones.

higher than this (cf. Table 3), and all are highly significant. There is also a slight, but significant, trend of increasing genetic differentiation with distance among the permanent streams $\left(b=0.032 ; R^{2}=0.30, P<0.05\right.$ : solid line in Fig. 2). In contrast, the two recolonized streams do not fit into this pattern and appear more or less equally similar to each of the permanent ones, with no increase in the quantity $F_{\mathrm{ST}} /\left(1-F_{\mathrm{ST}}\right)$ with geographical distance for them $(b=-0.002, P=0.8$ : dotted line in Fig. 2).

Assignment tests showed that trout from the two recolonized streams were assigned more evenly to all the other streams than were trout from the permanent streams (Table 4). Using the permanent populations as baseline populations and treating the recolonized ones as mixed populations in a mixed fishery analysis, yielded very similar results (Table 5) and clearly indicated the multiple origins of the trout in the two recolonized streams.

\section{Discussion}

Selecting a set of loci known to be polymorphic in Scandinavian brown trout made our estimates of heterozygosity high and not directly comparable to other genetic studies, which also include monomorphic loci. Most of these loci are frequently used to screen for genetic variation in brown trout, except $M A N^{*}, P E P-B^{*}$ and PEP-LT* (described by Jorde et al., 1991; Jorde, 1994). In contrast to a number of other genetic studies on brown trout, our samples did not show any variation in $G P I-1^{*}, G P I-2^{*}$ or $G P I-3^{*}$ and only very low variation at $M D H-4^{*}$ (cf. Crozier \& Ferguson, 1986; Moran et al., 1995; Rieffel et al., 1995). The overall amount of genetic differentiation (average $F_{\mathrm{ST}}=0.054$ ) was comparable to that found in other studies of anadromous brown trout [e.g. Paaver, $1989\left(G_{\mathrm{ST}}=0.06\right)$ and Moran et al., $\left.1995\left(F_{\mathrm{ST}}=0.077\right)\right]$.

Most streams conform to Hardy-Weinberg genotype proportions, indicating that they each harbour one more or less randomly mating population. The important exceptions were the overall deficiencies of heterozygotes detected in Allemannsbekken and Langangsvassdraget, which most likely represent Wahlund effects resulting from population substructuring within these permanent streams. In one of these (Langangsvassdraget) there is also significant linkage disequilibrium, a phenomenon that is expected in samples containing a mixture of populations (e.g. Campton, 1987). Such population substructuring has been reported earlier for the brown trout inhabiting streams (Carlsson et al., 1999) and still waters (Allendorf et al., 1976; Ryman et al., 1979; Ferguson \& Mason, 1981; Jorde \& Ryman, 1996), and appears to be a consequence of the strong natal homing in this species. 


\begin{tabular}{lcccccccc}
\hline & \multicolumn{8}{c}{ Donor population } \\
\cline { 2 - 9 } Recipient population & $1 \#$ & $2 \#$ & 3 & 4 & 5 & 6 & 7 & 8 \\
\hline 1 Steindalsbekken\# & 0.06 & 0.15 & 0.11 & 0.19 & 0.01 & 0.29 & 0.08 & 0.13 \\
2 Fjelldalselva\# & 0.05 & 0.18 & 0.14 & 0.21 & 0.04 & 0.23 & 0.13 & 0.09 \\
3 Pendalsbekken & 0.07 & 0.05 & 0.62 & 0.04 & 0.01 & 0.11 & 0.12 & 0.00 \\
4 Sævelibekken & 0.06 & 0.05 & 0.05 & 0.41 & 0.13 & 0.16 & 0.15 & 0.00 \\
5 Allemannsbekken & 0.02 & 0.06 & 0.10 & 0.12 & 0.46 & 0.10 & 0.02 & 0.12 \\
6 Songebekken & 0.09 & 0.08 & 0.08 & 0.15 & 0.06 & 0.38 & 0.14 & 0.08 \\
7 Mørefjærbekken & 0.06 & 0.00 & 0.15 & 0.10 & 0.01 & 0.14 & 0.28 & 0.16 \\
8 Langangsvassdraget & 0.01 & 0.06 & 0.10 & 0.10 & 0.05 & 0.16 & 0.16 & 0.35 \\
\hline
\end{tabular}

Table 4 The percentage of individuals assigned (i.e. having the highest likelihood) to each of the sampled populations calculated from multilocus genotypes using the GENECLASS software (Cornuet et al., 1999)

Table 5 Relative contribution from each of the six baseline populations to the two recolonized populations, using mixed fishery analysis (wHICHRUN 4.0; Banks \& Eichert, 2000). Note the similarity with the assignment percentages (Table 4)

\begin{tabular}{lcccccc}
\hline & \multicolumn{6}{c}{ Baseline population } \\
\cline { 2 - 7 } $\begin{array}{l}\text { Recolonized } \\
\text { population }\end{array}$ & 3 & 4 & 5 & 6 & 7 & 8 \\
\hline 1 Steindalsbekken\# & 0.18 & 0.21 & 0.05 & 0.29 & 0.08 & 0.19 \\
2 Fjelldalselva\# & 0.18 & 0.23 & 0.06 & 0.20 & 0.14 & 0.21 \\
\hline
\end{tabular}

The two recolonized streams, Fjelldalselva\# and Steindalsbekken\#, both displayed high linkage disequilibrium values. In contrast to the permanent stream where linkage disequilibrium was high (Langangsvassdraget; above), this result cannot readily be attributed to population substructuring, because there were no deviations from Hardy-Weinberg genotype proportions. A large amount of linkage disequilibrium could instead indicate a recent phase of population admixture, followed by random mating. Random mating effectively restores Hardy-Weinberg genotype proportions over a generation but linkage disequilibrium declines much more slowly, at most halving per generation with random mating (e.g. Hartl \& Clark, 1997). Hence, it is probable that the trout now occupying the two recolonized streams are descendants of a mixture of fish representing two or more genetically distinct donor populations. Because the two streams were treated with lime as late as 1992, at most two trout generations could have passed since recolonization when we sampled them in 1999. This time-span is probably too short to erode gametic phase disequilibrium in the proposed population mixture, but is sufficient to restore Hardy-Weinberg genotype proportions if mating occurs at random.

An alternative explanation for the high linkage disequilibrium values could be that the two presumed extinct and recolonized streams never went entirely extinct but instead experienced severe bottlenecks.
Random genetic drift during the bottleneck can generate linkage disequilibrium (e.g. Hartl \& Clark, 1997) but it should also lead to rapid genetic divergence and loss of genetic variation, which were not observed (cf. Tables 1 and 3 ).

The increased genetic differentiation with geographical distance observed for the permanent streams (cf. Fig. 2) resembles the theoretical expectation when dispersal ('migration') primarily occurs over short distances, such as between neighbouring streams (Wright, 1943; Kimura \& Weiss, 1964). Capture-mark-recapture studies of sea trout from southern Norway and elsewhere have found that straying (i.e. migration to a nonnatal stream), although rare, does indeed primarily occur between neighbouring streams (e.g. Svärdson \& Fagerström, 1982; Bror Jonsson, unpublished results from this area), thus providing a likely explanation for the observed genetic trend. Increasing genetic differentiation with distance has been reported for sea trout by Morán et al. (1995) and Hansen \& Mensberg (1998), but not for freshwater resident forms (e.g. Ryman, 1983; Crozier \& Ferguson, 1986; Ferguson, 1989), perhaps because of physical barriers to dispersal in the freshwater environment.

In contrast to the situation for the permanent streams, trout from the two recolonized streams do not follow the pattern of increased genetic differentiation with distance. Rather, while being very similar to each other genetically $\left(F_{\mathrm{ST}}=0.001\right.$ : Table 3$)$, the two recolonized trout populations appear about equally similar or dissimilar to trout from other streams within the area, regardless of distance. Genetically, the most similar of the permanent streams (Songebekken) is also one of the most distant ones and we presume that this similarity with the recolonized ones is a coincidence. Hence, recolonization of the sea trout populations appears not to have been by trout from the nearest neighbouring stream, or from any other single stream, but more likely by trout of mixed origins. This explanation is consistent with the assignment-percentages, which are lower for 
trout in the recolonized streams than for trout from any of the other streams (cf. Table 4). It also conforms to the mixed fishery analysis demonstrating multiple origins of recolonized populations (Table 5) and the linkage disequilibrium data discussed above.

The migrant pool model of recolonization (Wade \& McCauley, 1988) therefore seems the most appropriate to describe a situation where several source populations contribute substantially to the colonization. Nevertheless, there is no clear evidence in the results which points towards this system of populations constituting a true metapopulation. The two streams that went extinct due to acidification have no previous record of extinction for the last century (personal communication by Fish Management Officer Dag Matzov; Department of Environmental Affairs, County Governor in AustAgder) and the genetic differentiation among the other permanent populations indicates that this system is not extinction prone, in contrast with what is expected in a metapopulation. Spruell et al. (1999) studying bull trout populations and Fontaine et al. (1997) studying Atlantic salmon $(S$. salar) are among the few studies discussing whether Salmonids show metapopulation dynamics; neither study found evidence for such dynamics.

Recolonization of acid streams seems to reflect a different pattern of migration from that found among permanent streams, where straying mainly occurs among neighbours. Studies on marked sea trout demonstrate that some stray individuals do not return to their native stream nor go to neighbouring streams to spawn. Instead, these rare strayers are found in more or less remote streams where suitable environmental conditions can be found (Berg \& Berg, 1987; Lund \& Hansen, 1992). A mixture of such individuals from several sources could explain our finding of trout from a mixed origin in the two recolonized streams.

Our results on sea trout show that local extinction and recolonization may create greater genetic uniformity among sea trout populations, since the genetic characteristics of the extinct populations are most probably lost. To avoid such loss, management plans should be devised that allow quick responses to threats, such as acidification, that may cause drastic population decline and possibly extinction.

\section{Acknowledgements}

We thank Henry Knutsen and Bror Jonsson for excellent help with sampling of trout, and Bror Jonsson and Thrond Haugen and two anonymous referees for comments on an earlier version of this manuscript. HK was supported by the Institute of Marine Research, Flødevigen Marine Research Station, in cooperation with the Department of Environmental Affairs, AustAgder, and the Directorate for Nature Management. PEJ was supported by a post-doctoral grant from the Research Council of Norway.

\section{References}

AEbersold, P. B., WINANS, G. A., TEEL, D. J., MILNER, G. B. ET $A L$. 1987. Manual for starch gel electrophoresis: a method for detection of genetic variation. NOAA Tech. Report NMFS, 61, 1-19.

ALLENDORF, F. W. AND PHELPS, S. R. 1981. Use of allelic frequencies to describe population structure. Can. J. Fish. Aquat. Sci., 38, 1507-1514.

ALlENDORF, F. W., RYMAN, N. AND STÅHL, G. 1976. Genetic variation in Scandinavian brown trout (Salmo trutta L.): evidence of distinct sympatric populations. Hereditas, 83, 73-82.

BANKS, M. A. AND EICHERT, w. 2000. WHICHRUN (version 3.2) a computer program for population assignment of individuals based on multilocus genotype data. J. Hered., 91, 87-89.

BEAUdOU, D., BARIL, D., ROCHÉ, B., LE BARON, M. ET AL. 1995. Recolonization in a devastated Corsican river: Respective contribution of wild and domestic brown trout. Bull. Français de la Pêche et de la Pisciculture, 337, 259-266.

BERG, O. K. AND BERG, M. 1987. Migration of sea trout, Salmo trutta L., from the Vardnes river in northern Norway. J. Fish Biol., 31, 113-121.

CAMPTON, D. E. 1987. Natural hybridisation and introgression in fishes. Method of detection and genetic interpretations. In: Ryman, N. and Utter, F. (eds) Population Genetics and Fishery Management, pp. 161-192. University of Washington Press, Seattle.

CARLSSON, J., OLSEN, K. H., NILSSON, J., ØVERLI, Ø. ET AL. 1999. Microsatellites reveal fine-scale genetic structure in streamliving brown trout. J. Fish Biol., 55, 1290-1303.

CORNUET, J. M., PIRY, S., LUIKART, G., ESTOUP, A. ET AL. 1999. New methods employing multilocus genotypes to select or exclude populations as origins of individuals. Genetics, 153, 1989-2000.

CROZIER, W. W. AND FERGUSON, A. 1986. Electrophoretic examination of the population structure of brown trout, Salmo trutta L., from the Lough Neagh catchment, Northern Ireland. J. Fish Biol., 28, 459-477.

FERGUSON, A. 1989. Genetic differences among brown trout, Salmo trutta, stocks and their importance for the conservation and management of the species. Freshwater Biol., 21, 35-46.

FERGUSON, A. AND MASON, F. M. 1981. Allozyme evidence for reproductively isolated sympatric populations of brown trout Salmo trutta L., in Lough Melvin, Ireland. J. Fish Biol., 18, 629-642.

FONTAINE. P. M., DODSON, J. J., BERNATCHEZ, L. AND SLETTAN, A. 1997. A genetic test of metapopulation structure in Atlantic salmon (Salmo salar) using microsatellites. Can. J. Fish. Aquat. Sci., 54, 2434-2442.

GILPIN, M. 1991. The genetic effective size of a metapopulation. Biol. J. Linnaean Soc., 42, 165-175. 
HANSEN, M. M. AND MENSBERG, K. L. D. 1996. Founder effects and genetic population structure of brown trout (Salmo trutta) in a Danish river system. Can. J. Fish. Aquat. Sci., 53, 2229-2237.

HANSEN, M. M. AND MENSBERG, K. L. D. 1998. Genetic differentiation and relationship between genetic and geographical distance in Danish sea trout (Salmo trutta L.) populations. Heredity, 81, 493-504.

HARTL, D. L. AND ClARK, A. G. 1997. Principles of Population Genetics, pp. 96-107. Sinauer, Sunderland, MA.

HENRIKSEN, A., LIEN, L., ROSSELAND, B. O., TRAAEN, T. S. ET $A L$. 1989. Lake acidification in Norway: present and predicted fish status. Ambio, 18, 314-321.

JENSEN, K. W. AND SNEKVIK, E. 1972. Low pH levels wipe out salmon and trout populations in southernmost Norway. Ambio, 1, 223-225.

JORDE, P. E. 1994. Allozymes in Scandinavian brown trout (Salmo trutta L.). Report from the Division of Population Genetics, Stockholm University, Sweden.

JORDE, P. E. AND RYMAN, N. 1996. Demographic genetics of brown trout (Salmo trutta) and estimation of effective population size from temporal change of allele frequencies. Genetics, 143, 1369-1381.

JORDE, P. E., GITT, A. AND RYMAN, N. 1991. New biochemical genetic markers in the brown trout (Salmo trutta L.). J. Fish Biol., 39, 451-454.

KASTE, Ø. AND HÅVARDSTUN, J. 1998. Vannkvalitetsundersøkelse i kystnære småvassrag i Aust.-Agder 1995 og 1997. NIVArapport LNR 3743-97. (In Norwegian).

KIMURA, M. AND WEISS, G. H. 1964. The stepping stone model of population structure and the decrease of genetic correlation with distance. Genetics, 49, 561-576.

LEVINS, R. A. 1970. Extinction. Am. Math. Soc., 2, 77-107.

LEWONTIN, R. C. 1964. The interaction of selection and linkage. I. General considerations; heterotic models. Genetics, 49, 49-67.

LUND, R. A. AND L. P. HANSEN. 1992. Exploitation pattern and migration of the anadromous brown trout, Salmo trutta L., from the River Gjengedal, western Norway. Fauna Norvegica Series A, 13, 29-34.

MANTEL, N. 1967. The detection of disease clustering and a generalized regression approach. Cancer Res., 27, 209-220.

MORÁN, P., PENDÁS, A. M., GARCÍA-VÁZQUEZ, E., IZQUIERDO, J. I. ET AL. 1995. Estimates of gene flow among neighbouring populations of brown trout. J. Fish Biol., 46, 593-602.

NEI, K. AND CHESSER, R. K. 1983. Estimation of fixation indices and gene diversities. Ann. Hum. Genet., 47, 253-259.

ovidio, M. 1999. Annual activity cycle of adult brown trout (Salmo trutta L.): A radio-telemetry study in a small stream of the Belgian Ardenne. Bull. Français de la Pêche et de la Pisciculture, 352, 1-18.

PAAVER, T. K. 1989. Genetic differentiation of sea trout, Salmo trutta, populations of Estonian rivers. J. Ichthyol., 29, 37-43.

RAYMOND, M. AND F. ROUSSET. 1995. GENEPOP (version 1.2): Population genetics software for exact tests and ecumenicism. J. Hered., 86, 248-249.

RIEFFEL, M., STORCH, V. AND SCHREIBER, A. 1995. Allozyme variability of brown trout (Salmo trutta) populations across the Rheinanian-Danubian watershed in southwest Germany. Heredity, 74, 241-249.

ROUSSET, F. 1997. Genetic differentiation and estimation of gene flow from $F$-statistics under isolation by distance. Genetics, 145, 1219-1228.

RYMAN, N. 1983. Patterns of distribution of biochemical genetic variation in salmonids: Differences between species. Aquaculture, 33, 1-21.

RYMAN, N., ALLENDORF, F. W. AND STÅHL, G. 1979. Reproductive isolation with little genetic divergence in sympatric populations of brown trout (Salmo trutta). Genetics, 92, 247-262.

SHAKLEE, J. B., ALLENDORF, F. W., MORIZOT, D. C. AND WHITT, G. S. 1990. Gene nomenclature for protein coding loci in fish. Trans. Am. Fish Soc., 119, 2-15.

SIMONSEN, J. H. 1999. Registrering av sjøaurebekker i Aust.Agder. Report from the County Governor of Aust.-Agder, Arendal, Norway (In Norwegian).

SPRUELl, P., RIEMAN, B. E., KNUDSEN, K. L., UTTER, F. M. ET AL. 1999. Genetic population structure within streams: microsatellite analysis of bull trout populations. Ecol. Freshwater Fish, 8, 114-121.

STABEL, O. B. 1992. Olfactory control of homing behaviour in salmonids. In: Hara, T. J. (ed.) Fish Chemoreception, pp. 249-270. Chapman \& Hall, London.

STUART, T. A. 1957. The migration and homing behaviour of brown trout (Salmo trutta L.). Freshwater Salmon Fish. Res., 18, $1-27$.

SVÄRDSON, G. AND FAGERSTRÖM, Å. 1982. Adaptive differences in the long-distance migration of some trout (Salmo trutta L.) stocks. Report Inst. Freshw. Res., 60, 51-80.

WADE, M. J. AND MCCAUley, D. E. 1988. Extinction and recolonization: Their effects on the genetic differentiation of local populations. Evolution, 42, 995-1005.

WEIR, B. S. AND COCKERHAM, C. C. . 1984. Estimating $F$-statistics for the analysis of population structure. Evolution, 38, $1358-1370$.

WRIGHT, S. 1943. Isolation by distance. Genetics, 28, 114 138. 